\title{
Sleep, sedentary behavior and physical activity: changes on children's routine during the COVID-19
}

\section{Sono, comportamento sedentário e atividade física: mudanças na rotina de crianças durante a COVID-19}

\section{AUTHOR'S \\ Luís Carlos Barbosa Silva ${ }^{1}$ (D) \\ Cinthya Rafaella Magalhães da Nóbrega \\ Novaes $^{1}$ (iD) \\ Ronaldo Alexandre de Lima Júnior ${ }^{1}$ (D) \\ Bruno Barbosa Giudicelli ${ }^{1}$ (D) \\ Arnaldo Tenório da Cunha Júnior ${ }^{1}$ (D) \\ Maria Cecília Marinho Tenórioº (iD) \\ Clarice Maria de Lucena Martins ${ }^{3}$ (D) \\ Rafael Miranda Tassitano ${ }^{2}$ (iD) \\ 1 Laboratory of Cineanthropometry, Physical Activity and Health Promotion, Federal University \\ of Alagoas, Arapiraca, Alagoas, Brazil. \\ 2 Federal Rural University of Pernambuco, Recife, Pernambuco, Brazil. \\ 3 Federal University of Paraíba, João Pessoa, Paraíba, Brazil.}

\section{CORRESPONDING}

Luís Carlos Barbosa Silva

lcbarbosa@outlook.com

Avenida Manoel Severino Barbosa, s/n, Bairro Bom Sucesso, Arapiraca, Alagoas.

CEP: 57309-005.

DOI

$10.12820 /$ rbafs. $25 \mathrm{e} 0143$

\section{(c) $B$ BY}

This work is licensed under a Creative Commons Attribution 4.0 International License.

\begin{abstract}
Social isolation was adopted as a strategy to reduce the transmission speed of the severe acute respiratory syndrome of coronavirus 2 (SARS-CoV-2) in several countries in the world, including Brazil. As a result, schools were closed and the routines of children altered, affecting sleep, sedentary behavior, and physical activity. The present study aims to compare the children's weekly routine and time spent on sleep, sedentary behavior and physical activity before and during the Coronavirus disease 2019 (COVID-19) pandemic. A cross-sectional study with a quantitative and qualitative approach was performed, with 120 parents, mothers or guardians of children from 5 to 10 years of age of both sexes enrolled in 5 full-time schools in Arapiraca, Alagoas, Brazil. To meet the research objective, two interviews were conducted between 27 May and 5 June, out addressing aspects of sleep, sedentary behavior, and physical activity before and during the COVID-19 pandemic. In the analysis of quantitative data, the paired sample $t$ test was performed, while for qualitative data, discourse analysis was used. Significant differences ( $p<0.05)$ were found in the routine and in sleep time (increase 10\%) and screen time (increase 36\%) before vs during the COVID-19 pandemic, on weekdays and weekends. There was also a reduction in the practice of physical activity (54\%). Therefore, the findings indicate that behaviors during the COVID-19 pandemic could be harmful to children's health and that the school may be an important social environment to protect children from exposure to these behaviors.

Keywords: Coronavirus infections; Sleep; Sedentary behavior; Physical activity; Children

RESUMO

$O$ isolamento social foi adotado como estratégia para reduzir a velocidade de transmissão da sindrome respiratória aguda grave de coronavirus 2 ( $S A R S-C o V-2)$ em vários países do mundo, incluindo o Brasil. Como resultado, as escolas foram fechadas e as rotinas das crianças alteradas, afetando o sono, o comportamento sedentário e a atividade física. O presente estudo tem como objetivo comparar a rotina semanal das crianças e o tempo dispendido em sono, comportamento sedentário e atividade física antes e durante a pandemia da doença coronavirus 2019 (COVID-19). Estudo de caráter transversal e com abordagem quanti-qualitativa, com 120 pais, mães ou responsáveis de crianças de 5 a 10 anos de ambos os sexos, matriculadas em 5 escolas de tempo integral de Arapiraca, Alagoas, Brasil. Foram realizadas duas entrevistas, no periodo de 27 de Maio à 05 de Junho, abordando os aspectos do sono, comportamento sedentário e atividade física antes e durante a pandemia, a fim de atender o objetivo de pesquisa. Na análise dos dados quantitativos foi realizado o teste t de amostra emparelhada, já para os dados qualitativos foi utilizada a análise do discurso. Foram encontradas diferenças significativas $(p<0,05)$ na rotina e no tempo de sono (aumento de 10\%), no tempo de tela (aumento de 36\%) antes vs durante a pandemia de COVID-19, em dias de semana e finais de semana. Foi observada também uma redução na prática de atividade física (54\%). Portanto, os achados indicam comportamentos durante a pandemia de COVID-19 que podem ser prejudiciais à saúde das crianças e a escola pode ser um ambiente social importante na proteção a exposição de tais condutas.
\end{abstract}

Palavras-chave: Infecçôes por coronavirus; Sono; Comportamento sedentário; Atividade física; Criança.

\section{Introduction}

The World Health Organization (WHO) declared COVID-19 as a pandemic on March $11^{\text {th }}, 2020$. Social isolation was adopted as a strategy to reduce the transmission speed of the SARS-CoV-2 virus in several countries around the world, including Brazil. The State of Alagoas Government adopted social isolation on $18^{\text {th }}$ March 2020, according to Decree No. 69,541/201, allowing only the functioning of essential sectors, such as supermarkets, pharmacies, and health clinics in the state. Thus, public and private schools were closed, which corresponds to approximately 41,955 students remaining at home and participating in remote teaching activities. 
The suspension of classes leads to significant changes in the daily routine of children and, therefore, may change the 24-hour movement behavior (sleep, physical activity, and sedentary behavior) ${ }^{2}$. Investigating these behaviors, including light physical activity, seems to be important since they have critical implications for health, especially in the pediatric population ${ }^{3}$.

Lesser \& Nienhuis ${ }^{4}$ reported that physical activity behavior was altered during the COVID-19 pandemic, since $40.5 \%$ of the individuals investigated became more inactive. In another study conducted by Moore et. al. ${ }^{5}$, most Canadian children investigated did not reach the guidelines for physical activity (PA) (76.2\%) and screen time (83.5\%), while, in contrast, they met the recommendations for sleep time (69.9\%). This is particularly important since negative exposure to these behaviors is associated with increased body weight ${ }^{6}$, worse social and motor development $^{7}$, and loss of cardiorespiratory fitness for children ${ }^{8}$.

Historically, the school is a structured environment that is configured as an important social space in which children have access to supervised educational activities based on a curriculum ${ }^{9}$. In addition, it is the environment where children spend most of the day, especially those in full-time education. Studies indicate that school is the main environment where low-income children have access to opportunities for structured and supervised physical activity ${ }^{10-11}$. From this perspective, the structured days hypothesis ( $\mathrm{SDH})$ establishes that school days can positively model children's behavior, due to the fact that they include various activities such as: active commuting to school, playground, and Physical Education classes, added to limited screen time and more regulated sleep 9 .

The studies available in the literature only focused on research with a quantitative approach. However, in view of the emerging scenario, it is necessary to investigate the 24-hour movement behaviors during COVID-19, especially in children, through application of a quantitative-qualitative approach, as this may allow a broader view of the problem to be studied, as well as, enriching findings with data obtained within the natural context of their occurrence.

In view of the above, the present study aims to compare the children's weekly routine and time spent on sleep, sedentary behavior and physical activity before and during the COVID-19 pandemic.

\section{Methods}

This is a cross-sectional study, with a quantitative and qualitative approach and municipal coverage, which is part of a macro research project denominated "Development, implementation and evaluation of the physical activity axis in the municipal policy of integral education in Arapiraca, Alagoas" approved by the Research Ethics Committee of the Federal University of Alagoas (no CAEE: 29937020.3.0000.5013/CEP-UFAL).

The municipal education network of Arapiraca, Alagoas ranges from early childhood education to the second cycle of elementary education, with a total of 83 schools comprising 30,250 students, and including 10 full-time schools, corresponding to 4,681 students. The target population of this study was full-time school students.

All schools in the target population were invited to participate in the study and those which were interested and able to attend the data collection logistics remained in the study. Considering the atypical period, data collection was agreed with the Municipal Department of Education and Sport and occurred during the delivery of the food kit provided by the Arapiraca City Hall to the parents of the students of the municipal school system. As a result, and due to school logistics, 5 full-time schools in the Arapiraca, Alagoas municipal school system agreed to participate in the study. The delivery of food took place in the period between May 27 and June 5, 2020, and was organized according to the following biosafety protocol defined by the Secretariat itself: separation by year in which the child studies, separation by day and shift, mandatory use of a mask for everyone inside the school, alcohol gel available to everyone inside the school, five people allowed to enter the school at any time, $1.5 \mathrm{~m}$ distance between people, and immediate departure from the school after picking up the food kit. The personal protective equipment (PPE) and procedures adopted by the researchers during the data collection are as follows: use of a PFF2 mask, a facial protector with acetate shield, surgical apron in TNT 50 grams, use of $70^{\circ}$ liquid alcohol for sanitizing tables, chairs, pens, and box for storing the ICF, use of $70^{\circ}$ alcohol gel for hand hygiene, and a distance of 3 meters between the researcher and the interviewee. Three interviewers participated in the present research, and collected the maximum amount of information despite the adverse conditions arising from the short period of time available and the data collection logistics.

The instrument was elaborated by a committee formed by 15 researchers from the Federal University 
of Alagoas (UFAL), Rural Federal University of Pernambuco (UFRPE), and health and education professionals from the city of Arapiraca, Alagoas. Due to the limitations imposed to measure the instrument's psychometric properties, it was decided to develop a questionnaire specifically for this research based on questionnaires from other studies, such as the ElosPré Project and the Atitude Project. Subsequently, 22 mothers/guardians were re-interviewed during the qualitative part of the study.

The instrument consists of 58 questions organized into 3 sections: (1) Registration information; (2) Social (i.e. family income, items at home, access to public services) and demographic information (i.e. place of residence), according to the Brazilian Institute of Geography and Statistics (IBGE) criteria ${ }^{12}$; (3) Routine before COVID-19 and during COVID-19 quarantine/pandemic/outbreak. The 24-hour movement behaviors were: sleep, sedentary behavior, and physical activity.

The same question structure was adopted to assess these behaviors before and during the pandemic, on weekdays and on weekend days, as described below: Sleep: 1) On weekdays, what time does your child wake up to go to school?; 2) On weekdays what time does your child go to sleep?; 3) On weekend days, what time does your child wake up ?; 4) On weekend days, what time does your child go to sleep? The response was given in hours and minutes. Physical Activity: 5) On weekdays, how long (duration in minutes) does your child practice moderate to vigorous physical activity?; 6) On weekend days, how long (duration in minutes) does your child practice moderate to vigorous physical activity? The response was given in minutes. Sedentary Behavior: 7) On weekdays, how long (duration in minutes) does your child watch television ?; 8) On weekend days, how long (duration in minutes) does your child watch television?; 9) On weekdays how long (duration in minutes) does your child use a cell phone? 10) On weekend days how long (duration in minutes) does your child use a cell phone?; 11) On weekdays how long (duration in minutes) does your child use a computer or tablet?; 12) On weekend days how long (duration in minutes) does your child use a computer or tablet? The response was given in minutes. The total screen time was calculated by adding the time spent using TV, computer and smartphone.

The instrument was made available and used by researchers through Google Forms. All questions were explained in detail and with examples during the inter- view, which was performed face to face, with an average duration of 8 minutes for each interview. A qualitative interview was carried out through the WhatsApp application with 22 mothers in order to check the information, as well as to expand the focus of the investigation, and thus have a global view of the object of study. To deepen the routine issues, this qualitative part was composed of the following questions: 1) What is the importance of school in your child's life?; 2) What was your child's diet like before the pandemic and what is it like now?; 3) Tell us a little more about your child's routine. In relation to routine, what does he/she do in the morning, afternoon, and evening? However, for the current study, only the answers related to the child's routine, that is, the last question, were used in the results. It is worth mentioning that both the interviews via Google Forms and via WhatsApp were conducted by a team that was properly trained for the purpose. The training consisted of 2 meetings per week, totaling $4 \mathrm{~h} /$ week for a month to standardize data collection, in which the interviews were always performed by the same researcher.

Descriptive statistics were performed with absolute and relative frequency, for categorical variables, and means and confidence intervals for quantitative variables. The paired sample $t$ test was used to analyze sleep, sedentary behavior and physical activity before and during the COVID-19 pandemic, as well as weekdays vs weekends. All analyses were performed in the SPSS 18 program and $\mathrm{p}<0.05$ was adopted for statistical significance.

The respondents' answers to the three questions were accurately transcribed at the time they were spoken, respecting the argumentative structure elaborated by the interviewees, the logic constructed when answering, and the particularities of each person's form of expression. Any structures that did not conform to the formal language standard were left unchanged. Transcripts were analyzed using the thematic analysis method described by Braun \& Clarke ${ }^{13}$. This method consists of analyzing the transcribed discourses in search of thematic patterns that allow interpretation of the discourse of the subjects in the light of the investigated questions. The robustness of the analysis is sought through strict observance of the steps, described in the method, of (1) familiarization with the data; (2) generation of initial codes; (3) search for potential relevant themes; (4) review of the themes; (5) definition and nomenclature of the themes; and (6) production of the report.

The interpretive process of the researcher on the relevance of the themes to the issues raised in the in- 
vestigation is inherent to this type of analysis. Therefore, some precautions are necessary to avoid bias in the analysis, which goes beyond observing the steps described above. Among the possibilities, there is a careful description of the conditions of data collection, identifying possible biased sources, and detailed presentation of the researchers' understanding of the object of the investigation. In addition to these precautions, the thematic analysis was submitted to the scrutiny of the team of researchers involved. This type of procedure has been used previously in the literature ${ }^{14}$.

From the questions presented in the interview, three thematic axes of analysis were established a priori: I - Importance of school in children's lives; II - the impact of social isolation on children's diet; and III the impact of social isolation on the children's routine. For each axis, the steps of thematic analyses ${ }^{13}$ were carried out, establishing the themes arising from the interviewees' discourse.

\section{Results}

A total of 120 fathers (10.9\%), mothers (84.9\%), and/ or guardians of students (4.2\%) aged 5 to 10 years enrolled in full-time schools in Arapiraca, Alagoas were included. The final sample consisted of 120 students (50\% girls) with a mean age of $8.9( \pm 1.4)$ years. It was found that the majority of parents have low socioeconomic status, with an average monthly family income of $\mathrm{R} \$ 833.00$. Only $6.7 \%$ of respondents reported having a computer with internet at home, however, 59.2 $\%$ have a television with internet access. It was also ob- served that $80 \%$ of parents reported that children take active transport to school, mainly walking (Table 1).

Table 2 summarizes the comparisons of sleep, phys-

Table 1 - Characteristics of the study sample, 2020.

\begin{tabular}{|c|c|c|}
\hline Variables & $\mathrm{n}$ & $\%$ \\
\hline \multicolumn{3}{|l|}{ Sex } \\
\hline Boys & 60 & 50.0 \\
\hline Girls & 60 & 50.0 \\
\hline \multicolumn{3}{|l|}{ Birth order } \\
\hline First & 51 & 42.5 \\
\hline Second & 41 & 34.2 \\
\hline Third & 18 & 15.0 \\
\hline Fourth or later & 10 & 8.2 \\
\hline \multicolumn{3}{|l|}{ School Level } \\
\hline First year & 19 & 15.8 \\
\hline Second year & 20 & 16.7 \\
\hline Third year & 27 & 22.5 \\
\hline Fourth year & 43 & 35.8 \\
\hline Fifth year & 11 & 9.2 \\
\hline \multicolumn{3}{|c|}{ Socioeconomic level } \\
\hline $\mathrm{C} 1$ & 3 & 1.8 \\
\hline $\mathrm{C} 2$ & 33 & 27.9 \\
\hline D- E & 84 & 60.3 \\
\hline \multicolumn{3}{|c|}{ Family monthly income } \\
\hline$<\mathrm{R} \$ 1,045.00$ & 80 & 66.7 \\
\hline$\geq \mathrm{R} \$ 1,045.00$ & 40 & 33.3 \\
\hline \multicolumn{3}{|c|}{ Computer with internet at home } \\
\hline Yes & 8 & 6.7 \\
\hline No & 112 & 93.3 \\
\hline \multicolumn{3}{|c|}{ Television with internet at home } \\
\hline Yes & 49 & 40.8 \\
\hline No & 71 & 59.2 \\
\hline \multicolumn{3}{|c|}{ Active transportation to school } \\
\hline Yes & 96 & 80.0 \\
\hline No & 24 & 20.0 \\
\hline \multicolumn{3}{|c|}{ Travel time between home and school } \\
\hline$<15$ minutes & 68 & 56.7 \\
\hline$\geq 15$ minutes & 52 & 43.3 \\
\hline
\end{tabular}

Table 2 - Sleep, physical activity, total screen time, use of TV, cell phone, and computers before and during the COVID-19 pandemic on weekdays and weekend days.

\begin{tabular}{|c|c|c|c|c|}
\hline \multirow{2}{*}{ Outcomes (min/day) } & \multicolumn{2}{|c|}{ Before COVID-19 pandemic } & \multicolumn{2}{|c|}{ During COVID-19 pandemic } \\
\hline & Weekdays & Weekend days & Weekdays & Weekend days \\
\hline Sleep & $\begin{array}{c}581.4 \\
(570.9-591.9)^{\mathrm{a}, \mathrm{b}, \mathrm{c}}\end{array}$ & $\begin{array}{c}644.2 \\
(631.0-657.4)^{\mathrm{a}}\end{array}$ & $\begin{array}{c}639.7 \\
(626.5-653.5)^{\mathrm{b}}\end{array}$ & $\begin{array}{c}643.1 \\
(626.2-658.1)^{c}\end{array}$ \\
\hline Physical activity & $\begin{array}{c}30.4 \\
(19.3-43.1)\end{array}$ & $\begin{array}{c}20.2 \\
(11.6-30.1)\end{array}$ & $\begin{array}{c}17.1 \\
(8.0-26.7)\end{array}$ & $\begin{array}{c}14.6 \\
(7.0-22.7)\end{array}$ \\
\hline Screen time & $\begin{array}{c}196.8 \\
(173.6-224.9)^{\mathrm{b}, \mathrm{c}}\end{array}$ & $\begin{array}{c}213.4 \\
(188.7-239.4)^{\mathrm{d}, e}\end{array}$ & $\begin{array}{c}273.0 \\
(246.2-300.4)^{\mathrm{b}, \mathrm{d}}\end{array}$ & $\begin{array}{c}267.8 \\
(241.5-295.9)^{\mathrm{c}, \mathrm{d}, \mathrm{e}}\end{array}$ \\
\hline Cell phone & $\begin{array}{c}63.7 \\
(48.9-78.6)\end{array}$ & $\begin{array}{c}69.3 \\
(53.5-86.2)\end{array}$ & $\begin{array}{c}91.1 \\
(71.0-112.5)\end{array}$ & $\begin{array}{c}84.4 \\
(65.0-105.5)\end{array}$ \\
\hline Television & $\begin{array}{c}121.4 \\
(106.6-137.1)^{\mathrm{b}, \mathrm{c}}\end{array}$ & $\begin{array}{c}134.1 \\
(115.6-151.6)^{\mathrm{d}, \mathrm{e}}\end{array}$ & $\begin{array}{c}171.9 \\
(152.3-192.8)^{\mathrm{b}}\end{array}$ & $\begin{array}{c}175.4 \\
(154.7-196.9)^{\mathrm{c}, \mathrm{e}}\end{array}$ \\
\hline Computer & $\begin{array}{c}10.8 \\
(4.2-18.0)\end{array}$ & $\begin{array}{c}10.0 \\
(3.5-18.5)\end{array}$ & $\begin{array}{c}9.0 \\
(3.0-17.0)\end{array}$ & $\begin{array}{c}8.0 \\
(2.0-16.0)\end{array}$ \\
\hline
\end{tabular}

$\mathrm{a}=$ difference between before COVID-19 pandemic weekdays and before COVID-19 pandemic weekend days; $\mathrm{b}=$ difference between before COVID-19 pandemic weekdays and during COVID-19 pandemic weekdays; $\mathrm{c}=$ difference between before COVID-19 pandemic weekdays and during COVID-19 pandemic weekend days; $\mathrm{d}=$ difference between before COVID-19 pandemic weekend days and during COVID-19 pandemic weekdays; $\mathrm{e}=$ difference between before COVID-19 pandemic weekend days and during COVID-19 pandemic weekend days; $\mathrm{f}=$ difference between during COVID-19 pandemic weekdays and during COVID-19 pandemic weekend days. 
ical activity, total screen time, television, cell phone, and computer behaviors before and during the COVID-19 pandemic. Before the pandemic, sleep time was shorter on school days than on weekend days. From before to during COVID-19, a significant increase in total screen time and TV view was found on weekdays and weekend days, while sleep time increased only on weekdays. During the COVID-19 pandemic, no significant differences were found between weekdays and weekend days for any behaviors. Other comparisons showed significant differences in total screen time and TV viewing on weekdays before the pandemic compared to the weekend days during COVID-19.

As shown in the representation of the children's routine, without the obligation of school, weekdays and weekend days resemble each other with similar behaviors and opportunities, especially during the pandemic (Figure 1).

Table 3 presents the themes that emerged from the interviewees' discourse in relation to the impact of social isolation on the children's routines. The themes were related to (I) breaking the children's daily routine due to the lack of obligation to go to school, with some families being able to structure a new routine, while others were not, and consequent sleep alteration; (II) decreased pos- sibilities for active play, as the children are not interacting with other children, or do not have adequate space and materials; (III) increased screen time, related to the previous theme; and (IV) increased play time with parents.

\section{Discussion}

The present study aims to compare the weekly sleep routine, sedentary behavior and physical activity before and during the COVID-19 pandemic. A significant increase was observed in sleep time and in total screen time, and a non-significant decrease in the practice of physical activity.

Studies have reported a significant change in sleep time, with children going to bed and waking up later on weekends compared to weekdays ${ }^{15-17}$. Similar findings were reported in the current research, confirming the results mentioned above. This behavior could occur due to the absence of a day with a pre-defined structure, such as the school day (weekdays) ${ }^{9}$. During weekdays, the time that children go to bed tends to be earlier than weekends and the time they wake up is based on the start time of classes. The present study indicates that weekend days and weekdays during the pandemic are similar to weekend days before the pandemic. In general, this is similar to what occurs during the school vacation period ${ }^{18}$.
Sleep time

School hours

Outschool awake hours

Active transportation to school
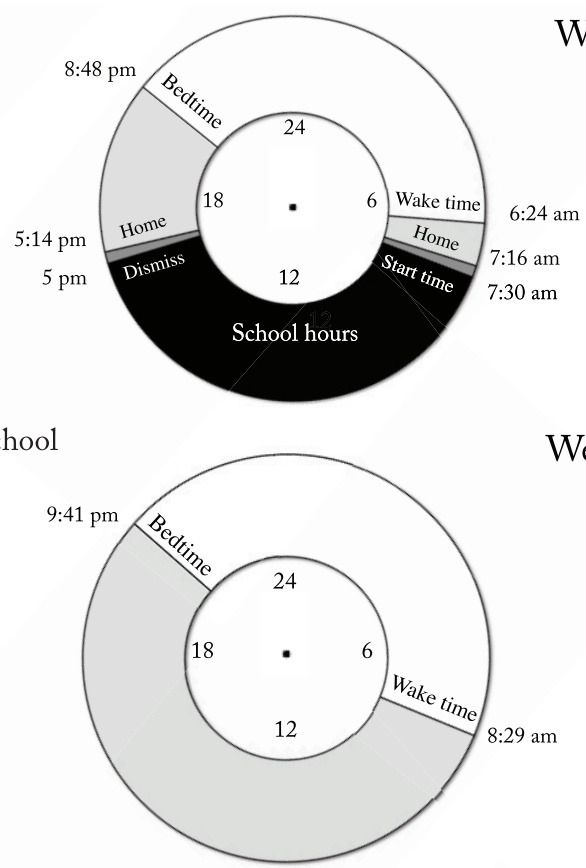

Before COVID-19 pandemic
Weekdays

Weekend days
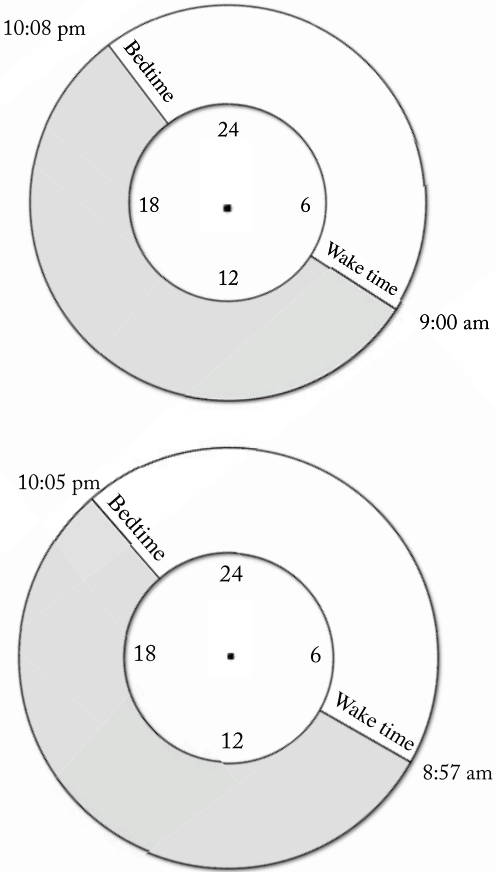

During COVID-19 pandemic

Figure 1 - Sleep time, school hours, waking hours out of school, and active transportation to and from school before and during the COVID-19 pandemic on weekdays and weekend days. 
Table 3 - Analysis themes related to the analysis axis, emerging from the interviewees' discourse, description, and speech extracts.

\begin{tabular}{ll}
\hline Themes & Description \\
\hline & $\begin{array}{l}\text { The lack of the obligation to go to school and } \\
\text { social isolation, which restricts the possibilities of } \\
\text { activities outside the home, led to the disruption of } \\
\text { the child's routine, with loss of fixed hours to wake } \\
\text { of routine } \\
\begin{array}{l}\text { and inability } \\
\text { to establish a } \\
\text { new one }\end{array}\end{array}$ \\
$\begin{array}{l}\text { up, eat meals, play, and sleep, among others. Parents } \\
\text { are unable to establish these routines without the } \\
\text { external pressure of school hours and while dealing } \\
\text { with the stress of social isolation themselves. }\end{array}$
\end{tabular}

Decreased for active play

Isolated in the home, parents report that children have reduced the time they spend playing, either because they are alone, or due to the inadequacy of spaces and materials. possibilities
Linked to the difficulty of playing games and play

Increased screen time activities in social isolation, added to the increase in the availability of screens for children, be it cell phones or other devices.
Discourse extract

S1A1: “[...] school is very important because they have a routine $[\ldots]$ at home we are not managing to have this routine with them"

S1A2: "[...] they are not waking up so early they are waking up later (short pause) so the schedule has changed a lot [...] then they come to have breakfast around noon [...]" S6A3: "During the morning when he gets up at 11 am he studies, plays [...]"

S11A4: "Every day her routine is to wake up early, 10 am or 11 am [...]"

S12A3: "In the morning she wakes up late because she is not studying so she wakes up late (short pause) [...] goes to sleep very late"

S17A3: "[...] I called him to eat, to have lunch, he didn't have breakfast, he didn't have lunch, because he is sleeping until this time [...]"

S1A2: "[...] they play very little because they stay in the house more I don't let them out [...]" S9A3: "[...]because there is nothing else to do, right, when the two of them do not play here in the area (short pause) but there is not much to do, after this virus, right, we feel the need to stay at home and children cannot play outside [...]" S22A3: "In the morning sleep, have lunch, in the afternoon do the lessons and then watch TV"

S1A2: “[...] they want to be on the cell phone more (long pause) then as I only have one phone for three here at home it's a war"

S7A3: "[...] watch, play a little. In the afternoon watch, play a little, and at night he watches more than he plays (short pause) [...]"

S8A3: "In the morning they watch cartoons $[\ldots]$ and watch cartoons $[\ldots]$ at night, indoors watching television [...]"

S9A3: "[...] in the afternoon they are always watching television on cell phones $[. .$.$] "$ S10A3: “[...] watch TV, [...] watch TV (short pause), watch TV, use the tablet, sleep about 10 hours"

S11A4: "[...] then it is straight to the tablet, straight, straight does nothing else" S11A7: "She doesn't play, she just stays on the tablet, her play is all on the tablet" S15A3: "[...] then watches it, spends a couple of hours watching it in the morning, [...] he watches the videos, as now the tasks are online and he does the tasks there then he will watch some more (short pause) [...] he eats dinner and watches some more [...]" S17A3: "[...] at night is on the telephone, stays on the telephone [...] when he wakes up, goes to the telephone [...]"

S21A3: "[...] he goes to the cell phone, when he doesn't have the cell phone he gets stressed because he has a little autism [...]"

With the social isolation and consequent Increased confinement of children in the home, fathers and time playing mothers engaged in playing with their children, with parents since they understand that there is a limitation in the possibilities of interaction between children.
S2A2: “[...] in the afternoon we play, I play with her [...] we play here my son and I, my daughter we play here inside the house understood? [...]"

Continue...

Regarding screen time, the present study identified a $36 \%$ increase in use during the pandemic versus before the pandemic (school period). Jago et al. ${ }^{19}$ found that the percentage of children who spend 2 hours or more per day involved in screen use increased by approximately $34 \%$ during weekend days compared to weekdays. Another study, with children from several European countries, reported that $52 \%$ of the sample is engaged in 2 hours or more of screen time on weekend days compared to $20 \%$ on weekdays ${ }^{20}$.

In the present study there was a reduction in children's physical activity time, before the COVID-19 pandemic was 30 minutes and during the COVID-19 pandemic the time spent decreased to 17 minutes. The study by Moore et al. ${ }^{5}$, developed with children and young people in Canada, to assess the immediate im- pact of the restrictions that the pandemic imposed on the movement and playful behaviors, observed that children and young people were less active, played less outside the home, participated in more recreational activities based on a screen, and slept more during the pandemic, corroborating the current study. Additionally children are more active on weekdays compared to weekend days ${ }^{21-22}$. Studies that propose to investigate 24-hour movement behaviors in the period of COVID-19 in low-income Brazilian children, are scarce, however some studies have evaluated these behaviors with different outcomes, such as executive function ${ }^{23}$ and compliance with the movement guidelines ${ }^{24}$. These findings are important since they have implications for the development of obesogenic behaviors and consequently other diseases ${ }^{25}$. 


\begin{tabular}{|c|c|c|}
\hline Themes & Description & Discourse extract \\
\hline $\begin{array}{l}\text { Deregulation } \\
\text { of routine and } \\
\text { establishment } \\
\text { of a new one }\end{array}$ & $\begin{array}{l}\text { In this category are families that have established } \\
\text { a routine, more or less different from the routine } \\
\text { prior to social isolation, which combines established } \\
\text { schedules, educational activities, with or without } \\
\text { remote assistance from schools, free playtime, } \\
\text { games with parents, and screen time. }\end{array}$ & 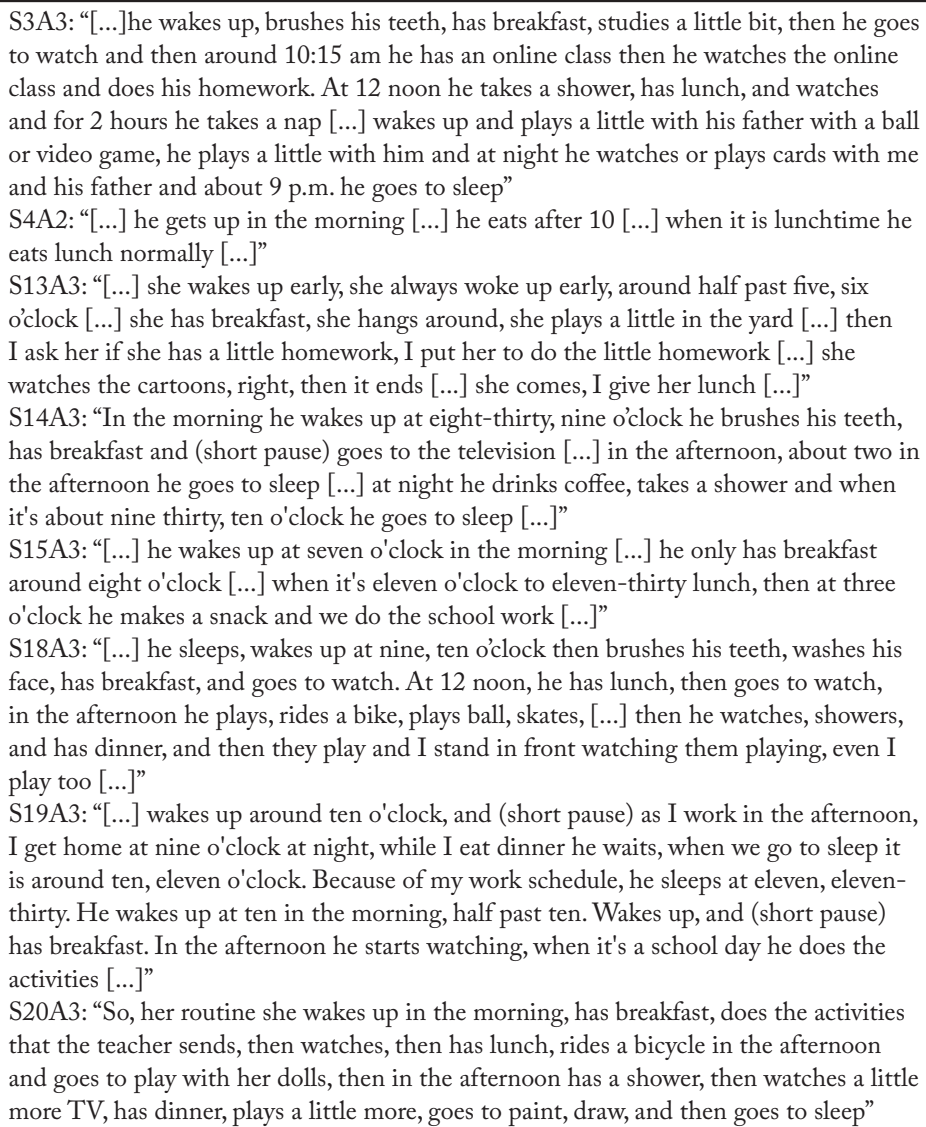 \\
\hline
\end{tabular}

Legend: S1A1 = subject 1 audio 1 .

Alterations in bedtime and waking up routines, limited physical space and possibilities for other activities, absence from school, as presential classes are suspended, and the use of cell phones, computers, and TV for remote education, and also in leisure time are peculiar characteristics of this moment. The period of isolation at home because of the COVID-19 pandemic seems to have been a fundamental factor that may have contributed to the results of the present research, which is corroborated by the discourse of the interviewees, since they point out that the absence from school causes disruption in the children's daily routine, with prejudice to habits considered healthy and expansion of negative behaviors 9 .

Among the negative behaviors reported by the participants were alterations in sleep, an increase in screen time, and a reduction in physical activities, represented by the act of playing, which confirms the data from the quantitative analysis. The first two effects mentioned, altered sleep and increased screen time, appear in the discourse as directly related to the disruption of the routine resulting from the absence of the obligation to go to school. In these cases, the family appears unable to structure a new routine, either due to the parents' professional commitments, the effects of stress caused by the pandemic, or social isolation.

However, there were reports of families that have managed to structure a new routine to compensate for the lack of an obligation to go to school, establishing new fixed times to wake up, eat meals, and engage in playful activities. In some cases, parents started to interact with their children in games, active or not, which represents an impact that can be positive. On the other hand, the decrease in the possibilities of active play, although related to the closure of schools, also appears in the participants' discourse as a result of the lack of adequate space for children who are unable to leave the home, confirming the findings of this and other studies.

It is possible to consider some points characterized as limitations of the study, among them, self-reported measures and information bias related to information on the previous period. However, the following strate- 
gies were adopted to minimize the limitations: (a) faceto-face interview using examples for better understanding; (b) re-interview with a sub-group of mothers; and (c) participation of the same interviewers throughout data collection. On the other hand, investigating these behaviors in low-income children in a pandemic period can be considered a strength of the present study.

The results of this study suggest that during the COVID-19 pandemic, children enrolled in full-time schools in Arapiraca, Alagoas have a longer sleep time, longer screen usage and less physical activity when compared to the period before the pandemic, both on weekdays and on weekend days. These behaviors can be associated with negative outcomes for children's health and the school could be an important social environment to protect them from exposure to these behaviors, considering that the school has characteristics of a structured environment, and that it can establish a consolidated routine for children. In addition, given the unprecedented COVID-19 pandemic, public schools at Arapiraca have an important role by providing healthy foods and social support to the families. However, one must be cautious about the results, longitudinal evidence, with larger samples, is necessary for better inferences about the findings and possible advances in the area, as well as for the creation of strategies to face future pandemics.

\section{Conflict of interest}

The authors declare no conflict of interest.

\section{Contribution of each author to the study}

Silva LCB, contributed to the initial study design, data collection, writing the introduction, methods, results, discussion, and critical review of the text. Novaes CRMN, contributed to the initial study design, data collection, and critical review of the text. Lima Júnior RA, contributed to the initial study design and data collection. Giudicelli BB, contributed to data analysis, writing of the methods, results, and discussion, and critical review of the text. Cunha Júnior AT, contributed to the initial study design and critical review of the text. Tenório MCM, contributed to the initial study design and critical review of the text. Martins CML, contributed to the initial study design and critical review of the text. Tassitano RM, contributed to the initial study design, writing the introduction, methods, results, and discussion, data analysis, critical review of the text, and guidance on the manuscript.

\section{Acknowledgements}

The authors would like to thank the Municipal Department of
Education and Sport of Arapiraca, Alagoas and all the managers of the full-time schools in the municipal education network of Arapiraca, Alagoas

\section{References}

1. Governo do Estado de Alagoas. Decreto 69.541, de 18 de Março de 2020. [citado em 2020 jul 17]. Disponível em: http:// www.imprensaoficialal.com.br/wp-content/uploads/2020/03/ DOEAL-20_03_2020-SUPLEMENTO.pdf.

2. Tremblay MS, Chaput JP, Adamo KB, Aubert S, Barnes JD, Choquete L, et al. Canadian 24-hour Movement Guidelines for the early years (0-4 years): An integration of physical activity, sedentary behaviour, and sleep. BMC Public Health. 2017;17(5):874-89.

3. Chaput JP, Carson V, Gray CE, Tremblay MS. Importance of all movement behaviors in a 24 hour period for overall health. Int J Environ Res Public Health. 2014;11(12):12575-81.

4. Lesser IA, Nienhuis CP. The Impact of COVID-19 on Physical Activity Behavior and Well-Being of Canadians. Int J Environ Res Public Health. 2020;17(11):3899-11.

5. Moore SA, Faulkner G, Rhodes RE, Brussoni M, ChulakBozzer T, Ferguson LJ, et al. Impact of the COVID-19 virus outbreak on movement and play behaviours of Canadian children and youth: a national survey. Int J Behav Nutr Phys Act. 2020;17(85):1-11.

6. Tarp J, Child A, White T, Westgate K, Bugge A, Grontved $A$, et al. Physical activity intensity, bout-duration, and cardiometabolic risk markers in children and adolescents. Int J Obes. 2018;42(9):1639-50.

7. Mostafavi R, Ziaee V,Akbari H,Haji-Hosseini S. The effects of spark physical education program on fundamental motor skills in 4-6 year-old children. Iran J Pediatr. 2013;23(2):216-19.

8. Carson V, Lee E, Hewitt L, Jennings C, Hunter S, Kuzik N, et al. Systematic review of the relationships between physical activity and health indicators in the early years ( $0-4$ years). BMC Public Health. 2017;17(Supp1 5):33-63.

9. Brazendale K, Beets MW, Weaver RG, Pate RR, TurnerMcGrievy GM, Kaczynski AT, et al. Understanding differences between summer vs school obesogenic behaviors of children: the structured days hypothesis. Int J Behav Nutr Phys Act. 2017;14(100):1-14.

10. Howe CA, Freedson PS, Alhassan S, Feldman HA, Osganian $\mathrm{SK}$, et al. A recess intervention to promote moderate-tovigorous physical activity. Pediatr. Obes. 2012;7(1):82-8.

11. Ramstetter CL, Murray R, Garner AS. The crucial role of recess in Schools. J School Health. 2010;80(11):517-26.

12. IBGE. Síntese de indicadores sociais: uma análise das condições de vida da população brasileira: 2019. Rio de Janeiro: IBGE, 2019. [citado em 2020 ago 24]. Disponível em: https://biblioteca.ibge.gov.br/visualizacao/livros/ liv101678.pdf.

13. Braun V, Clarke V. Using the matic analysis in psychology. Qualit Res Psych. 2006;3(2):77-101.

14. Cumming SP, Brown DJ, Mitchell S, Bunce J, Hunt D, Hedges C, et al. Premier League academy soccer players experiences of competing in a tournament bio-banded for biological maturation. J Sports Sciences. 2018;36(7):757-65.

15. Michels N, De Henauw S, Eiben G, Hadjigeorgiou C, Hense $S$, Hunsberger M, et al. Effect of the IDEFICS multilevel obesity prevention on children's sleep duration. Obes Rev. 2015;16(S2):68-77.

16. Chaput JP. Is sleep deprivation a contributor to obesity in children?. Eat weight disord. 2016;21(1):5-11. 
17. Wiggs L, Sparrowhawk M, Barnett AL. Parent report and actigraphically defined sleep in children with and without developmental coordination disorder; links with fatigue and sleepiness. Front Pediatr. 2016;4(81):1-14.

18. Brazendale K, Beets MW, Turner-McGrievy GM, Kaczynnski AT, Pate RR, Weaver RG. Children's obesogenic behaviors during summer versus school: A within-person comparison. J School Health. 2018;88(12):886-92.

19. Jago R, Thompson JL, Sebire SJ, Wood L, Pool L, Zahra J, et al. Cross-sectional associations between the screen-time of parents and young children: differences by parent and child gender and day of the week. Int J Behav Nutr Phys Act. 2014;11(54):1-8.

20. Santaliestra-Pasías AM, Mouratidou T, Verbestel V, Bammann K, Molnar D, Sieri S, et al. Physical activity and sedentary behaviour in European children: the IDEFICS study. Public Health Nutr. 2014;17(10):2295-06.

21. Brooke HL, Corder K, Atkin AJ, Van Sluijs EMF.A systematic literature review with meta-analyses of within and between day differences in objectively measured physical activity in school aged children. Sports Med. 2014;44(10):1427-38.
22. Atkin AJ, Sharp SJ, Harrison F, Brage S, Van Sluijs, EMF. Seasional variation in children's physical activity and sedentary time. Med Sci Sports Exerc. 2016;48(3):449-56.

23. Bezerra TA, Clark CCT, Filho ANS, Fortes LS, Mota JAPS, Duncan MJ, et. al.24-hour movement behaviour and executive function in preschoolers: a compositional and isotemporal reallocation analysis. Eur J Sport Sci. 2020;17:1-9.

24. Martins CML, Clark CCT, Bandeira PFR, Mota J, Duncan MJ. Association between compliance with the 24-hour movement guidelines and fundamental movement skills in preschoolers: A network perspective. Int J Environ Res Public Health. 2020;17(15):5443.

25. Chaput JP, Saunders TJ, Carson V. Interactions between sleep, movement and other non-movement behaviours in the pathogenesis of childhood obesity. Obes Rev. 2017;18(1):7-14.

Recebido: 28/08/2020

Aprovado: 14/10/2020

\section{Quote this article as:}

Silva LCB, Norvaes CRMN, Lima Júnior RA, Giudicelli BB, Cunha Júnior AT, Tenório MCM, Martins CML, Tassitano RM. Sleep, sedentary behavior and physical activity: change on children's routine during the COVID-19. Rev Bras Ativ Fis Saúde. 2020;25:e0143. DOI: 10.12820/ rbafs. $25 e 0143$ 